\title{
Impact of basic civility techniques on satisfaction in a nursing course
}

\author{
Sandra Rogers* \\ University of Kentucky, United States
}

Received: February 5, 2022

DOI: $10.5430 /$ jnep.v12n7p 8
Accepted: February 16, $2022 \quad$ Online Published: March 7, 2022

URL: https://doi.org/10.5430/jnep.v12n7p8

\begin{abstract}
Background and objective: Uncivil student behaviors witnessed in nursing courses have been linked to uncivil clinical behaviors when students graduate and begin practice in the hospital setting. This can result in less than favorable patient outcomes. Hence the importance of building civility in nursing education. This study explored student satisfaction related to basic civility strategies implemented in an entry level nursing course.

Methods: This descriptive study utilized course evaluations to measure and compare student satisfaction before and after implementing basic civility techniques in an entry level nursing course. The university Institutional Review Board (IRB) reviewed and approved this project.

Results: The overall evaluation score was significantly different from the fall semester to the spring semester, $\mathrm{U}=223.0, p=$ .004 .

Conclusions: Basic civility techniques add to the course satisfaction as reported by students.
\end{abstract}

Key Words: Civility, Nursing education, Nursing student, Nurse faculty

\section{BACKGROUND AND PURPOSE}

Although not limited to health care settings, an increase in uncivil student behavior in nursing courses and clinical settings has become a concern as witnessed by instructors in higher education. ${ }^{[1]}$ These uncivil behaviors include, but are not limited to, students arriving late to class, playing on their phones or laptops during class, and being disrespectful to their instructors and classmates. ${ }^{[2]}$ Incivility in the classroom and clinical setting can interfere with teaching and learning and therefore needs to be managed. Incivility management can be described as the process by which teachers create and maintain appropriate behavior of students while overseeing their interactions and learning. ${ }^{[2]}$ Effective classroom management promotes a learning environment by maintaining the students' attention, keeping them focused on the task at hand, and being productive academically during the learning experience. ${ }^{[3]}$

By understanding the problem of incivility and addressing it by implementing effective management strategies is crucial for instructors in higher education. Basic civility building strategies include setting ground rules, demonstrating immediacy, and normalizing feedback. ${ }^{[4]}$ Setting ground rules can include guidelines and policies while demonstrating immediacy could include promptly answering student emails, calling a student by name, and nonverbal behavior, such as eye contact. Normalized feedback is anchored in respect and provides feelings of safety in both the receiver and the giver. ${ }^{[1]}$ Overall, this develops an environment of trust and transparency.

*Correspondence: Sandra Rogers; Email: sandy.rogers@uky.edu; Address: University of Kentucky, United States. 
The literature has shown the importance of building civility in nursing education. Disruptive, uncivil behaviors in students have been linked to uncivil clinical behaviors in practicing nurses as well, which can result in less than favorable patient outcomes. This can include the fear of asking for guidance or help from uncivil nurses. ${ }^{[5]}$ Therefore, it is vital that uncivil behavior be addressed in nursing programs before the behavior has a chance to permeate the nursing workforce environment.

Basic civility techniques utilized in the classroom included setting ground rules, demonstrating immediacy, and normalizing feedback as well as including the profession's code of conduct (ANA or American Nurses Association's Code of Ethics) in the syllabus. ${ }^{[3,6,7]}$

These principles should be introduced on the first day of class and continued throughout the 16-week course.

The purpose of this descriptive study was to describe student satisfaction related to basic civility strategies implemented in an entry level nursing course classroom with a retrospective look at course evaluations compared over two semesters.

\section{METHOD}

\subsection{Data analysis}

Standard course evaluations were retrospectively retrieved from two sections of the same course. Students in both sections had responded to a 12-question survey at the end of the course on the standard university evaluation. The first set of evaluations occurred in the fall semester $(n=30)$, prior to implementation of the civility techniques of setting ground rules, demonstrating immediacy, normalizing feedback, and including the ANA Code of Ethics in the course's syllabus. The second set of evaluations were collected from different students at the end of the spring semester of the same course $(n=31)$ where conscious implementation of the civility techniques had occurred. The same professor taught both sections of the course, fall and spring.

Demographics of the university nursing program includes $94 \%$ female and $6 \%$ male; $33 \%$ white; $17 \%$ black; $15 \%$ Hispanic; and $10 \%$ Asian. All evaluation questions were responded to on a 5-point Likert-type scale $(1=$ strongly disagree, $2=$ disagree, $3=$ neutral, $4=$ agree, $5=$ strongly agree; $1=$ very poor, $2=$ poor, $3=$ fair, $4=$ good, $5=$ excellent; or $1=$ never, $2=$ almost never, $3=$ sometimes, $4=$ fairly often, $5=$ very often). All data were imputed into IBM SPSS statistical software, and all analyses were conducted using SPSS. The alpha level for statistical significance was set to .05 .

The study was a pre-test (fall evaluations) X post-test (spring evaluations) between-subjects design. First, descriptive statistics for each evaluation question, and total evaluation score were reported. Then, the statistical assumptions of the independent-samples t-test were assessed to determine whether the parametric or non-parametric equivalent test was more appropriate. Finally, each evaluation question was analyzed to determine whether a statistical difference in pre- and post- intervention (civility) occurred. Additionally, a total evaluation score was calculated using the total mean for each evaluation question. ${ }^{[8-11]}$

\section{Results}

A total of 61 students were administered evaluations following the course over two semesters: 30 students in the fall semester, 31 students in the following spring semester. However, five students in the fall semester did not respond to any evaluation questions, and therefore not included in the subsequent analyses. The assessed 12 items were shown in Table 1.

Table 1. Evaluation questions

\begin{tabular}{|l|l|}
\hline Question 1 & How would you rate this course as a learning experience? \\
\hline Question 2 & I was motivated to take responsibility for my own learning in this course. \\
\hline Question 3 & I was challenged to think deeply about subject matter \\
\hline Question 4 & I was encouraged to ask my own questions and seek answers. \\
\hline Question 5 & The instructor was responsive when students had questions or needed assistance. \\
\hline Question 6 & The instructor explained course content in a way I could understand. \\
\hline Question 7 & The instructor used teaching methods that helped me learn. \\
\hline Question 8 & During class how often did you engage in learning activities such as problem solving, group work, etc.? \\
\hline Question 9 & I received useful feedback from the instructor. \\
\hline Question 10 & I received grades and feedback on assignments / tests in a timely manner (as communicated by the instructor). \\
\hline Question 11 & The grading policies in this course were clear. \\
\hline Question 12 & The grading policies in this course were consistently followed. \\
\hline
\end{tabular}


Table 2. Descriptive statistics for end of course evaluations (all students)

\begin{tabular}{|c|c|c|c|}
\hline & Fall & Spring & Total \\
\hline \multicolumn{4}{|l|}{ Question 1} \\
\hline Mean (SD) & $4.04(0.89)$ & $4.84(0.45)$ & $4.48(0.79)$ \\
\hline Median & 4 & 5 & 5 \\
\hline Range & $2-5$ & $3-5$ & $2-5$ \\
\hline$n$ & 25 & 31 & 56 \\
\hline \multicolumn{4}{|l|}{ Question 2} \\
\hline Mean (SD) & $4.60(0.58)$ & $4.80(0.41)$ & $4.71(0.50)$ \\
\hline Median & 5 & 5 & 5 \\
\hline Range & $3-5$ & $4-5$ & $3-5$ \\
\hline $\mathrm{N}$ & 25 & 30 & 55 \\
\hline \multicolumn{4}{|l|}{ Question 3} \\
\hline Mean (SD) & $4.32(0.63)$ & $4.87(0.35)$ & $4.62(0.56)$ \\
\hline Median & 4 & 5 & 5 \\
\hline Range & $3-5$ & $4-5$ & $3-5$ \\
\hline $\mathrm{N}$ & 25 & 30 & 55 \\
\hline \multicolumn{4}{|l|}{ Question 4} \\
\hline Mean (SD) & $4.48(0.59)$ & $4.83(0.38)$ & $4.67(0.51)$ \\
\hline Median & 5 & 5 & 5 \\
\hline Range & $3-5$ & $1-5$ & $3-5$ \\
\hline $\mathrm{N}$ & 25 & 30 & 55 \\
\hline \multicolumn{4}{|l|}{ Question 5} \\
\hline Mean (SD) & $4.60(0.65)$ & $4.71(0.82)$ & $4.66(0.75)$ \\
\hline Median & 5 & 5 & 5 \\
\hline Range & $3-5$ & $1-5$ & $1-5$ \\
\hline $\mathrm{N}$ & 25 & 31 & 56 \\
\hline \multicolumn{4}{|l|}{ Question 6} \\
\hline Mean (SD) & $4.12(1.10)$ & $4.65(0.92)$ & $4.41(1.02)$ \\
\hline Median & 5 & 5 & 5 \\
\hline Range & $2-5$ & $1-5$ & $1-5$ \\
\hline $\mathrm{N}$ & 25 & 31 & 56 \\
\hline \multicolumn{4}{|l|}{ Question 7} \\
\hline Mean (SD) & $4.00(1.00)$ & $4.65(0.92)$ & $4.36(1.00)$ \\
\hline Median & 4 & 5 & 5 \\
\hline Range & $2-5$ & $1-5$ & $1-5$ \\
\hline $\mathrm{N}$ & 25 & 31 & 56 \\
\hline \multicolumn{4}{|l|}{ Question 8} \\
\hline Mean (SD) & $3.84(0.85)$ & $4.77(0.50)$ & $4.36(0.82)$ \\
\hline Median & 4 & 5 & 5 \\
\hline Range & $2-5$ & $3-5$ & $2-5$ \\
\hline $\mathrm{N}$ & 25 & 31 & 56 \\
\hline \multicolumn{4}{|l|}{ Question 9} \\
\hline Mean (SD) & $4.68(0.48)$ & $4.47(0.90)$ & $4.56(0.74)$ \\
\hline Median & 5 & 5 & 5 \\
\hline Range & $4-5$ & $1-5$ & $1-5$ \\
\hline $\mathrm{N}$ & 25 & 30 & 55 \\
\hline \multicolumn{4}{|l|}{ Question 10} \\
\hline Mean (SD) & $4.72(0.46)$ & $4.70(0.92)$ & $4.71(0.74)$ \\
\hline Median & 5 & 5 & 5 \\
\hline Range & $4-5$ & $1-5$ & $1-5$ \\
\hline $\mathrm{N}$ & 25 & 30 & 55 \\
\hline \multicolumn{4}{|l|}{ Question 11} \\
\hline Mean (SD) & $4.76(0.44)$ & $4.77(0.77)$ & $4.76(0.64)$ \\
\hline Median & 5 & 5 & 5 \\
\hline Range & $4-5$ & $1-5$ & $1-5$ \\
\hline $\mathrm{N}$ & 25 & 30 & 55 \\
\hline \multicolumn{4}{|l|}{ Question 12} \\
\hline Mean (SD) & $4.76(0.44)$ & $4.77(0.77)$ & $4.76(0.64)$ \\
\hline Median & 5 & 5 & 5 \\
\hline Range & $4-5$ & $1-5$ & $1-5$ \\
\hline$N$ & 25 & 30 & 55 \\
\hline \multicolumn{4}{|c|}{ Total Evaluation Score } \\
\hline Mean (SD) & $4.41(0.62)$ & $4.68(0.74)$ & $4.56(0.70)$ \\
\hline Median & 4.67 & 5 & 5 \\
\hline Range & $3.00-5.00$ & $1.80-5.00$ & $1.80-5.00$ \\
\hline$N$ & 25 & 31 & 56 \\
\hline
\end{tabular}

Across both semesters and across all items, most students
(92.48\% of responses across all items) evaluated the course as a 4 or 5 (good or excellent; agree or strongly agree, often or very often). Descriptive statistics for each item, and the total evaluation score across both semesters are reported in Table 2. Statistical Assumptions of independent samples t-test. Before conducting the primary analysis, the assumptions of the independent samples $t$-test were assessed. The first two assumptions associated with this analysis are that the independent variable is 1) a categorical variable with two levels (i.e. pre-civility evaluations $\&$ post-civility evaluations), and 2) the levels must be unrelated groups (i.e. different students in pre- and post- evaluations). The next assumption is that the dependent variable is continuous. The present study uses a 5-point Likert-type scale, an ordinal variable, as the dependent variable. Some research has demonstrated support for the use of Likert type data as approximately continuous. 6 9 Therefore, the present study treats the evaluation responses as continuous data.

Then, the assumption of normality was assessed using the Shapiro-Wilk test of Normality. A significant $p$ value (i.e. $<.05)$ indicates that the shape of the distribution is significantly different than the normal distribution. The distribution of responses to each evaluation item, as well as the total evaluation score, were significantly different from a normal distribution (see Table 3). As such, the non-parametric equivalent to the independent samples t-test, Mann-Whitney U test, was selected as the most appropriate statistical analysis. The Mann-Whitney $U$ test is used when the dependent variable is either ordinal or continuous, but not normally distributed.

Table 3. Shapiro-Wilk test of normality for all evaluation questions

\begin{tabular}{llll}
\hline \multirow{2}{*}{ Items } & \multicolumn{3}{l}{ Shapiro-Wilk test of normality } \\
\cline { 2 - 4 } & Statistic & df & $\boldsymbol{p}$ \\
\hline Question 1 & 0.666 & 55 & $<.001$ \\
Question 2 & 0.589 & 55 & $<.001$ \\
Question 3 & 0.654 & 55 & $<.001$ \\
Question 4 & 0.618 & 55 & $<.001$ \\
Question 5 & 0.536 & 55 & $<.001$ \\
Question 6 & 0.623 & 55 & $<.001$ \\
Question 7 & 0.682 & 55 & $<.001$ \\
Question 8 & 0.741 & 55 & $<.001$ \\
Question 9 & 0.608 & 55 & $<.001$ \\
Question 10 & 0.445 & 55 & $<.001$ \\
Question 11 & 0.404 & 55 & $<.001$ \\
Question 12 & 0.404 & 55 & $<.001$ \\
Total Evaluation Score & 0.266 & 55 & $<.001$ \\
\hline
\end{tabular}

Evaluation Results. Evaluations of the course the semester prior to and following the introduction of civility techniques 
were compared using a series of Mann-Whitney U Tests to determine whether civility improved students' evaluations of the course. Across both semesters, ratings the average ratings were high (see Table 2). However, the overall evaluation score was significantly different from the fall semester to the spring semester, $U=223.0, p=.004$. Overall, students' average evaluation rating was higher in the spring semester than the fall semester (see Figure 1).

Additionally, the shapes of the frequency distributions for responses to overall evaluations were different from the fall semester to the spring semester. Perfect evaluation scores (i.e., 5.00) were much more frequent in the spring semester $(n=19)$ than the fall semester $(n=6)$ (see Figure 2$)$.

Furthermore, six of the evaluation items were significantly different from fall to spring; Questions 1, 3, 4, 6, 7, and 8 (See Table 4 for $U$ and $Z$ statistics, and significance levels). For each of these items, students in the spring semester had

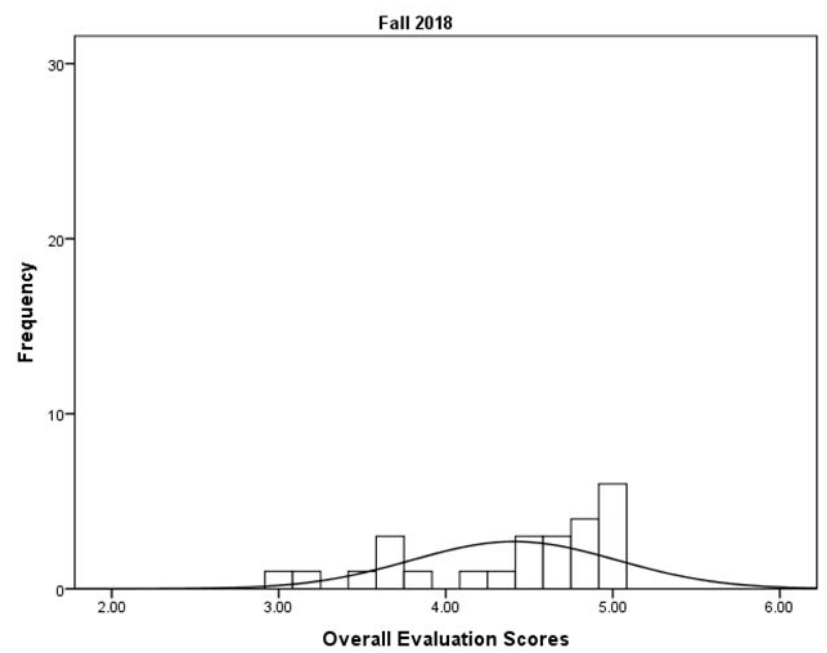

higher evaluations than students in the fall semester. Furthermore, for each of these items, there were a higher frequency of "5" responses (i.e. Excellent, strongly agree, and very often) (see Table 5).

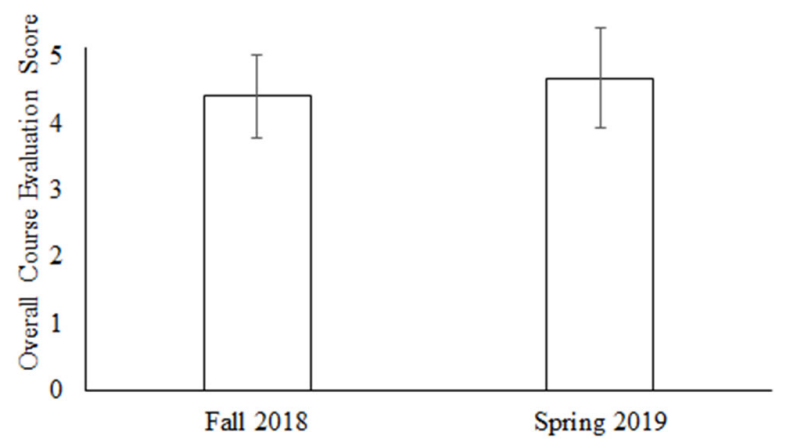

Figure 1. Average course evaluation scores for fall and spring semesters

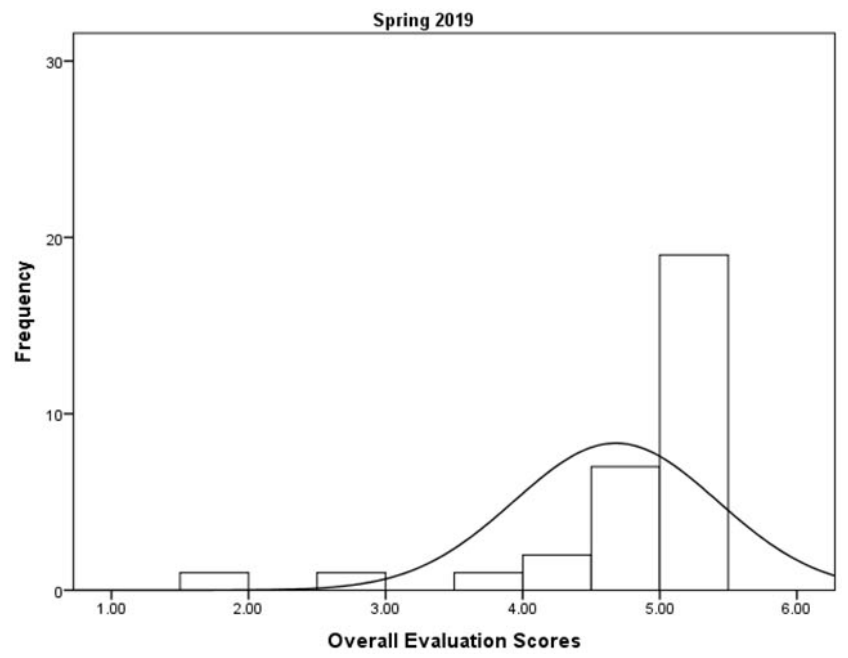

Figure 2. Frequency Histograms of Overall Evaluation Scores for Fall and Spring Semesters

\section{SUMmary}

A series of Mann-Whitney U test comparisons were conducted across each individual evaluation items to assess whether students' evaluations differed before and after civility techniques were introduced into the classroom. The present study found that students' overall evaluation scores were higher in the spring semester (after the civility techniques were introduced) than in the fall (prior to civility techniques in the classroom). Furthermore, six of the 12 evaluation items were significantly higher in the spring semester compared to the fall semester (Questions 1, 3, 4, 6, 7, and 8). For each of these items, more students reported a perfect evaluation (i.e., a score of 5) in the spring semester compared to the fall semester. There was no significant difference across semesters for questions 2, 4, 9, 10, 11, and 12 .
Table 4. Mann-Whitney U Test statistics and significance levels for each evaluation item

\begin{tabular}{llll}
\hline \multirow{2}{*}{ Items } & \multicolumn{3}{l}{ Mann-Whitney U Test } \\
\cline { 2 - 4 } & $\mathbf{U}$ & $\mathbf{Z}$ & $\boldsymbol{p}$ \\
\hline Question 1 & 171.5 & -4.15 & $<.001^{* * *}$ \\
Question 2 & 312.0 & -1.38 & .169 \\
Question 3 & 196.0 & -3.64 & $<.001^{* * *}$ \\
Question 4 & 255.0 & -2.52 & $.012^{*}$ \\
Question 5 & 330.0 & -1.29 & .198 \\
Question 6 & 273.0 & -2.28 & $.022^{*}$ \\
Question 7 & 228.0 & -3.04 & $.002^{* *}$ \\
Question 8 & 150.0 & -4.36 & $<.001^{* * *}$ \\
Question 9 & 345.5 & -0.60 & .550 \\
Question 10 & 327.0 & -1.17 & .243 \\
Question 11 & 338.0 & -0.93 & .350 \\
Question 12 & 338.0 & -0.93 & .350 \\
Total Evaluation Score & 223.0 & -2.84 & $.004^{* *}$ \\
\hline$p<.05^{*} ; p<.005^{* *} ;<.001^{* * *}$ & & &
\end{tabular}


Table 5. Response to evaluation items that were significantly different across semesters

\begin{tabular}{|c|c|c|c|c|c|}
\hline Items & Evaluation $\mathbf{R}$ & tings & & & \\
\hline Question 1: How would you rate this course as & Very Poor & Poor & Fair & Good & Excellent \\
\hline a learning experience? & (1) & (2) & (3) & (4) & (5) \\
\hline Fall semester & 0 & 2 & 3 & 12 & 8 \\
\hline Spring semester & 0 & 0 & 1 & 3 & 27 \\
\hline $\begin{array}{l}\text { Question 3: I was challenged to think deeply } \\
\text { about subject matter }\end{array}$ & $\begin{array}{l}\text { Strongly } \\
\text { Disagree (1) }\end{array}$ & Disagree (2) & $\begin{array}{l}\text { Neutral } \\
\text { (3) }\end{array}$ & $\begin{array}{l}\text { Agree } \\
\text { (4) }\end{array}$ & $\begin{array}{l}\text { Strongly Agree } \\
\text { (5) }\end{array}$ \\
\hline Fall semester & 0 & 0 & 2 & 13 & 10 \\
\hline Spring semester & 0 & 0 & 0 & 4 & 26 \\
\hline $\begin{array}{l}\text { Question 4: I was encouraged to ask my own } \\
\text { questions and seek answers }\end{array}$ & $\begin{array}{l}\text { Strongly } \\
\text { Disagree (1) }\end{array}$ & Disagree (2) & $\begin{array}{l}\text { Neutral } \\
\text { (3) }\end{array}$ & $\begin{array}{l}\text { Agree } \\
\text { (4) }\end{array}$ & $\begin{array}{l}\text { Strongly Agree } \\
\text { (5) }\end{array}$ \\
\hline Fall semester & 0 & 0 & 1 & 11 & 13 \\
\hline Spring semester & 0 & 0 & 0 & 5 & 25 \\
\hline $\begin{array}{l}\text { Question 6: The instructor explained course } \\
\text { content in a way I could understand }\end{array}$ & $\begin{array}{l}\text { Strongly } \\
\text { Disagree (1) }\end{array}$ & Disagree (2) & $\begin{array}{l}\text { Neutral } \\
\text { (3) }\end{array}$ & $\begin{array}{l}\text { Agree } \\
\text { (4) }\end{array}$ & $\begin{array}{l}\text { Strongly Agree } \\
\text { (5) }\end{array}$ \\
\hline Fall semester & 0 & 3 & 4 & 5 & 13 \\
\hline Spring semester & 1 & 1 & 0 & 4 & 25 \\
\hline $\begin{array}{l}\text { Question 7: The instructor used teaching } \\
\text { methods that helped me learn }\end{array}$ & $\begin{array}{l}\text { Strongly } \\
\text { Disagree (1) }\end{array}$ & Disagree (2) & $\begin{array}{l}\text { Neutral } \\
\text { (3) }\end{array}$ & $\begin{array}{l}\text { Agree } \\
\text { (4) }\end{array}$ & $\begin{array}{l}\text { Strongly Agree } \\
\text { (5) }\end{array}$ \\
\hline Fall semester & 0 & 2 & 6 & 7 & 10 \\
\hline Spring semester & 1 & 1 & 0 & 4 & 25 \\
\hline $\begin{array}{l}\text { Question 8: How often did you engage in } \\
\text { learning activities? }\end{array}$ & $\begin{array}{l}\text { Never } \\
\text { (1) }\end{array}$ & $\begin{array}{l}\text { Almost Never } \\
\text { (2) }\end{array}$ & $\begin{array}{l}\text { Sometimes } \\
\text { (3) }\end{array}$ & $\begin{array}{l}\text { Fairly Often } \\
\text { (4) }\end{array}$ & $\begin{array}{l}\text { Very Often } \\
\text { (5) }\end{array}$ \\
\hline Fall semester & 0 & 1 & 8 & 10 & 6 \\
\hline Spring semester & 0 & 0 & 1 & 5 & 25 \\
\hline
\end{tabular}

\section{CONCLUSIONS AND IMPLICATIONS}

Nursing course instructors must be aware of and address classroom incivility. Uncivil behavior disrupts learning and students expect the behavior to be addressed by faculty. The uncivil behaviors students exhibit in a nursing classroom could lead to uncivil behaviors in the clinical setting and potentially impact patient care. Techniques are available to confront and limit bad behavior in the classroom including basic civility building strategies such as setting ground rules, demonstrating immediacy, and normalizing feedback. ${ }^{[4]}$

As shown by this study, augmenting basic civility techniques to an entry level nursing course can improve course satisfaction and potentially impact uncivil behaviors as demonstrated in the literature. It is vital that uncivil behavior be addressed in nursing programs before the behavior has a chance to permeate the nursing workforce environment. This includes creating a culture of civility in the classroom with dignity and respect for all. This is accomplished by setting ground rules on day one of class, becoming familiar with the students with information they have shared, and making feedback something desired by the students. Another important aspect is role modeling the behaviors we want our students to exhibit. The outcome of improved satisfaction by students on course evaluations after civility techniques were added could be a driver for more faculty to implement the techniques in their classrooms.

\section{CONFlicts OF InTEREST Disclosure}

The author declares that there is no conflict of interest.

\section{REFERENCES}

[1] Eka NG, Chambers D. Incivility in Nursing Education: A Systematic Literature Review. Nurse Education in Practice. 2019; 39(1): 45-54 PMid:31382114 https://doi.org/10.1016/j.nepr.2019.06 .004
[2] Yrisarry N, Neuberger L, Miller AN. Instructor Response to Uncivil Behaviors in the Classroom: An Application of Politeness Theory. Journal of the Scholarship of Teaching and Learning. 2019; 19(4): 32-42. https://doi.org/10.14434/josotl.v19i4. 24505

[3] Clark KR. Managing the Higher Education Classroom. Radiologic 
Technology. 2017; 89(2): 210-213.

[4] Palumbo R. Incivility in nursing education: An intervention. Nurse Education Today. 2018; 66: 143-148. PMid:29704701 https: //doi.org/10.1016/j.nedt.2018.03.024

[5] Sauer PA, Thompson CE, Verzella MM. Empowering Nursing Students to Address Incivility. Clinical Simulation in Nursing. 2018; 21 : 40-45. https://doi.org/10.1016/j.ecns. 2018.06.004

[6] Donathan LN, Hanks M, Dotson AT. Minimizing Incivility in the Online Classroom. Radiologic Technology. 2017; 89(1): 88-91.

[7] Rawlins L. Faculty and Student Incivility in Undergraduate Nursing Education: An Integrative Review. Journal of Nursing Education. 2017a; 56(12): 709-716. PMid:29206260 https://doi.org/10.3 928/01484834-20171120-02

[8] Johnson DR, Creech JC. Ordinal measures in multiple indicator models: A simulation study of categorization error. American Socio- logical Review. 1983; 48: 398-407. https://doi.org/10.2307/ 2095231

[9] Norman G. Likert scales, levels of measurement and the "laws" of statistics. Advances in Health Sciences Education. 2010; 15(5): 625-632. Available from: https://link.springer.com/arti cle/10.1007\%2Fs10459-010-9222-y\#citeas PMid:20146096 https://doi.org/10.1007/s10459-010-9222-y

[10] Sullivan G, Artino Jr. AR. Analyzing and Interpreting Data from Likert-Type Scales. Journal of Graduate Medical Education. 2013; 5(4): 541-542. PMid:24454995 https://doi.org/10.4300/JG ME-5-4-18

[11] Zumbo BD, Zimmerman DW. Is the selection of statistical methods governed by level of measurement? Canadian Psychology. 1993; 34: 390-400. https://doi.org/10.1037/h0078865 